\title{
Nuclear waste store could be built within 25 years, say Lords
}

[LONDON] The British government should immediately resume planning for disposal of civilian and military nuclear waste underground, according to a report published this week by a House of Lords committee.

The Lords Select Committee on Science and Technology suggests that such a repository could be planned and built within 25 years. The findings come two years after environmentalists and the local authority managed to kill the UK government's plans to build a permanent store at Sellafield, Cumbria (see Nature 386, 423-424; 1997). They will re-ignite a controversy over the disposal of more than 70,000 cubic metres of nuclear waste in Britain that is currently stored above ground.

The report acknowledges that, although there is an international consensus in favour of deep underground disposal of radioactive wastes, this is not always a popular option. It says the government needs to build public trust in the concept by starting public consultation on a new national radioactive waste management policy. A central aim of the policy should be to give the public and parliament more say in decision-making than they have had in the past.

Local authorities, the report says, may need incentives to "volunteer" to host potential repositories, as happens in other countries. It adds that residents near a potential repository site may need compensation for the adverse impact on house prices, businesses and other forms of "blight" experienced by communities with nuclear neighbours.

The committee says that any new policy should also cover wastes from the nuclear

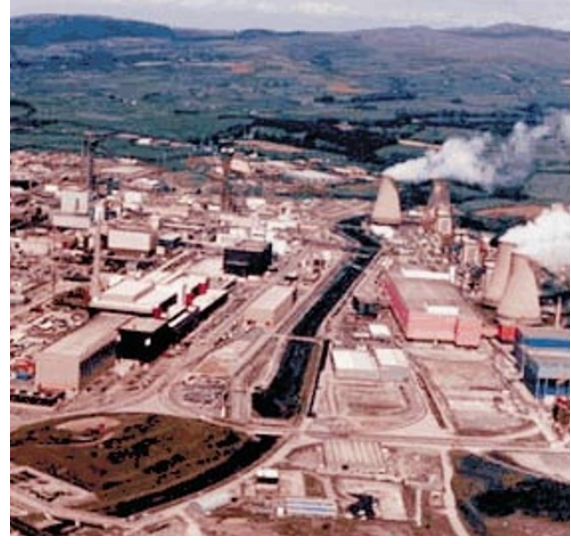

Dig deep: nuclear waste stored on the surface at Sellafield could yet go underground.

weapons programme, and plutonium from defence sources and civil nuclear power plants. Until now, plutonium has not been classed as a waste owing to its potential use as a reactor fuel. The report says that "there is no reason to store plutonium which is surplus to all foreseeable requirements".

A repository should remain open for research and monitoring until the government is satisfied that the wastes pose a negligible threat to human health and the environment, says the report. The repository would then be sealed off, although retrieval of wastes should still be possible.

A key recommendation comes in the form of a blueprint for a new policy structure for managing radioactive waste. The committee calls for the establishment of a new statutory body, the Nuclear Waste Management Commission. This should draw up a

\section{Gaps remain in knowledge of waste behaviour}

Although deep disposal is its preferred way to deal with radioactive waste, the House of Lords Select Committee on Science and Technology acknowledges that many technical questions about this remain unanswered.

'Initial 'guesstimates' about the rates at which waste packages will corrode and the rates at which radionuclides will be leached out into groundwater have been replaced by firmer estimates based on a firmer understanding of the physical and chemical processes involved," says the report.

But it adds that many gaps in the knowledge remain. These include the effects of earthquakes and future changes in climate on the rates and patterns of groundwater flow. The report says that movement of groundwater through ordinary fractured rock is difficult to model, without factoring in the effect of an earthquake.

The report adds that, although changes in sea levels and the timing of future glaciations can be predicted, the means to predict the effects of climate changes on groundwater flow are incomplete. It adds: "Techniques such as palaeohydrogeology, in which attempts are made to reconstruct past groundwater conditions as an indicator of future ones, are in their infancy."

A "further major type of uncertainty", it says, is the extrapolation of the results of short-term laboratory experiments to thousands of years and longer. This applies to canister corrosion and waste leaching. list of possible sites, commission and monitor research, and oversee construction of the repository. The commission's members would be drawn from a wide range of backgrounds, and it would report to parliament.

A Radioactive Waste Disposal Company funded by the nuclear industry would carry out site investigation, research and repository construction. Its work programme would need approval from the commission, and its research would be published and peer reviewed. The company would decide the final choice of site, but this would need to be ratified by both houses of parliament before being put to a public inquiry.

The structure of the two bodies is similar to that envisaged more than 20 years ago in a report from the Royal Commission on Environmental Pollution, which was chaired by Brian Flowers, former vice-chancellor of the University of London, who is also a member of the Lords committee.

Successive governments only partially implemented the Flowers recommendations. The government's existing Radioactive Waste Management Advisory Committee, for example, was given no powers to commission research, and has no representation from environmentalist groups.

Nirex, the nuclear-industry-funded company set up in 1982 to manage waste from civilian nuclear power plants, suffered from a reputation as an excessively secretive organization, beholden to the nuclear industry and reluctant to publish its findings.

The Lords report says that no solution will be viable without public acceptance. But, like the government, the Lords committee is unconvinced that the views of environmentalist groups are the same as those of the broader public, and is keen to explore ways of establishing those views.

"Some new methods are currently being tried which do not give undue preference to minorities at the expense of the 'silent majority'” the report says. This is partly a reference to an ongoing consensus conference, in which a panel of lay people will in the coming weeks deliver its verdict on the future of radioactive waste.

Environmental groups such as Greenpeace insist that radioactive wastes must be stored above ground permanently on or near sites where they are produced, both to reduce transport journeys, and so that the wastes can be monitored and retrieved if necessary.

Other groups want the wastes to be stored above ground at least while research and development on the safety of the deep repository concept is completed. Ehsan Masood 